\title{
CYLD Gene Mutation
}

National Cancer Institute

\section{Source}

National Cancer Institute. CYLD Gene Mutation. NCI Thesaurus. Code C150494.

A change in the nucleotide sequence of the CYLD gene. 